\title{
CORRECTION
}

\section{Correction to: Jean Baptiste Octave Landry (1826-1865)}

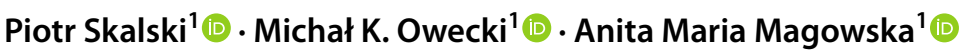

Published online: 13 December 2018

(c) The Author(s) 2018

\section{Correction to: Journal of Neurology \\ https://doi.org/10.1007/s00415-018-9120-4}

The original version of this article unfortunately contained a mistake. Title was incorrect. The corrected title is given below.

Jean Baptiste Octave Landry (1826-1865)

Open Access This article is distributed under the terms of the Creative Commons Attribution-NonCommercial 4.0 International License (http://creativecommons.org/licenses/by-nc/4.0/), which permits any noncommercial use, distribution, and reproduction in any medium, provided you give appropriate credit to the original author(s) and the source, provide a link to the Creative Commons license, and indicate if changes were made.

The original article can be found online at https://doi.org/10.1007/ s00415-018-9120-4.

Piotr Skalski

skal.p@ump.edu.pl

1 Department of History and Philosophy of Medical Sciences,

Poznan University of Medical Sciences, Przybyszewskiego

37a, 60365 Poznan, Poland 